\title{
HANDELEN EN DENKEN IN HANNAH ARENDTS EXISTENTIEFILOSOFIE
}

\author{
William Denayer
}

\section{Inleiding ${ }^{1}$}

Er is wat aan de hand met de receptie van het werk van Hannah Arendt. Haar vernieuwende en indringende studie over het totalitarisme, haar ontologie van het actieve, de studie over de revoluties en het boek over Eichmann hebben vanaf hun publicatie een groot lezerspubliek bereikt. Als geen ander heeft Arendt, na zelf met de nazistische terreur geconfronteerd geweest te zijn, over politieke fenomenen en het wezen van de politiek nagedacht. ${ }^{2}$ Haar laatste, onvoltooid gebleven, werk over de faculteiten van de geest krijgt echter niet diezelfde belangstelling. Voor de lezers die Arendt kennen om haar meeslepende, steeds polemische, schrijfstijl vertegenwoordigt The Life of the Mind waarschijnlijk de anticlimax van haar oeuvre. Voor deze situatie zijn verschillende redenen te noemen. The Life of the Mind zet in met een probleemstelling - behoedt het denken ons tegen boosaardigheid en zo ja, hoe ? - waar de schrijfster, begaan met de deconstructie van de filosofie, verder nauwelijks aandacht lijkt aan te besteden. Zonder het afsluitende deel over het oordelen blijft het werk ook onvolledig. Zonder Judging ontbreekt niet alleen de tekst over het oordelen. De delen over het denken en het willen blijven achter zonder de in het vooruitzicht gestelde synthese, de bespreking van het leven van de geest. De belangrijkste reden waarom The Life of the Mind niet in dezelfde mate als de overige studies in de belangstelling staat is dat niet zo makkelijk valt in te zien wat de moeilijke en onkarakteristiek moeizaam geschreven reflecties over (het verkeerd begrijpen door filosofen van) het denken, het willen en het oordelen met haar vroegere werk over de politiek te maken hebben.

In de literatuur erkent men het belang van The Life of the Mind voor Arendts politieke theorie niet. Het werk wordt nauwelijks in haar politieke oeuvre gesitueerd. De meeste commentatoren beschouwen het boek als Arendts terugkeer naar haar oorspronkelijke studieobject, de metafysica. ${ }^{3}$ Het is echter onjuist te stellen dat het werk los van de centrale preoccupatie over de politieke praktijk zou staan. In wat volgt leg ik uit hoe de verbinding tussen geest en wereld bij Arendt gedacht moet worden. Haar gedachten over de werking van de geest hebben 
duidelijk consequenties voor haar fenomenologie van de politiek. Ze brengen in de conceptie van het politieke handelen een consistentie aan die voordien afwezig was. Om dit te verhelderen bied ik eerst een bespreking van het handelen. Nadien schenk ik aandacht aan het leven van de geest.

\section{Het actieve leven}

Hannah Arendt legt in het 'Woord vooraf' van The Human Condition (1958) uit waarom zij een werk met zulk een fantastische titel heeft geschreven. $\mathrm{Zij}$ heeft haar onderzoek laten leiden door de angst dat de moderne mens verwikkeld is geraakt in een rebellie tegen het bestaan zoals het is gegeven. De auteur vreest dat het civilisatieproces en vooral de greep van het totalitarisme de menselijke vermogens, en dan vooral het vermogen te handelen, getransformeerd hebben. Daarom dringt zich de nood op de menselijke capaciteiten nauwkeurig te omschrijven.

Arendt verdeelt het actieve leven onder in arbeid, werk en actie. Arbeid beantwoordt aan de noodzakelijke, dagdagelijkse-repetitieve, inspanningen ter bevrediging van elementaire behoeften. Werk bestaat uit het aanmaken van duurzame objecten volgens een vooraf bedacht plan. Homo faber, de ambachtsman en kunstenaar, redt zich uit de onderwerping aan de natuur door een specifiek menselijke wereld te realiseren. Het werk heeft echter een louter utilitaristisch referentiekader als limiet. Animal laborans en homo faber zijn bestanddelen van de gemeenschap, maar participeren niet aan de gemeenschappelijke activiteit of praxis.

Handelen beantwoordt aan een publiek bediscussiëren en nemen van politiekethische beslissingen op basis van afgewogen praktische oordelen. Kenmerkend is dat in de vertoogruimte mensen aan elkaar verschijnen in hun wezenlijke gedaante. De actie actualiseert, als humaniserende en wereldconstituerende praktijk, het distinctieve 'wie' van het individu. De identiteit actualiseert op haar beurt de pluraliteit, de combinatie van gelijkwaardigheid en existentiële uniciteit. De pluraliteit resulteert in het verschil der meningen en de politiek valide vorm van spreken, het uiten van opinies. Pluraliteit beantwoordt aan 'het web' van interactieve symbolische relaties dat zich hernieuwt door de geboorte van nieuwe generaties.

Arendts onderscheid tussen het zelf en de identiteit is hier essentieel. Het zelf staat in voor de instandhouding van het leven. Deze relatie met de noodzakelijkheid maakt van het zelf een ongedifferentieerde, gedetermineerde, in essentie triviale grootheid. De mens verkrijgt zijn distinctieve identiteit wanneer hij zijn zelf, bij het betreden van de publieke sfeer, achter zich laat. Arendt spreekt 
van 'verschijning en actualisatie'. De constitutie van de identiteit voltrekt zich door de tussenkomst van de wil. De wil maakt het handelen mogelijk doordat hij, voor de duur van de handeling, de actor van zijn belangrijkste obstakels, zijn biologische en psychologische zelf en zijn denken, willen en oordelen verlost. Arendt schrijft dat de wil zich manifesteert als een coup d'état. De beeldspraak maakt duidelijk dat de relatie tussen de projecten van de wil en de politieke vrijheid van de actor niet causaal is. Het is niet omdat de wil projecten vormt dat de actor in de publieke ruimte zal handelen of dit in overeenstemming met de revindicaties van de wil zal doen. Politieke vrijheid staat niet onder het dicaat van de wil. Indien dit het geval zou zijn, zou het actualiseren van vrijheid van de wil afhankelijk zijn. Het belang van de coup d'état bestaat er in dat hij alle determinerende antecedenten voor het handelen wegveegt. Daardoor verzekert hij het innovatieve karakter van de handeling.

De identiteit leidt tot de generering van realiteitsgevoel of 'wereldsheid'. De 'wereldsheid' manifesteert zich door met anderen wezenlijke interacties aan te gaan. Op deze wijze ontstaat een gevoel van 'thuisheid' op de wereld. Wereldsheid, thuisheid, en pluraliteit bekomt men uitsluitend in het samen handelen. Arendt maakt dit duidelijk door de actie met het publieke bestaan van de ambachtsman te vergelijken. Diegenen die elkaar ontmoeten in de publieke ruimte van de markt doen dit in de eerste plaats niet in hun hoedanigheid van mensen, maar als producenten en verkopers van waren. De ambachtsman leidt een publiek, maar geen politiek bestaan. Specifiek voor het handelen is dat tussen de leden van de vertoogsruimte een authentiek menselijk samenzijn heerst, dat er van werkelijke identiteitsontsluiting sprake kan zijn.

Dit laatste werkt machtsgeneratief. Macht beantwoordt niet aan de instrumentalisatie van de wil van anderen, maar aan de opbouw van een gemeenschappelijke wil. Macht volgt ook niet uit een door illocutionaire taalhandelingen verkregen consensus. Arendt stelt dat men over te nemen beslissingen dikwijls geen overeenstemming bereikt. De dissensus belemmert de machtsgenerativiteit niet. De macht ontstaat uit het gegeven dat elkeen zijn opinie kan verdedigen terwijl alle anderen er open voor staan. Wetten zijn voor Arendt, zoals bij Montesquieu, geen louter opgelegde bepalingen, maar belichamingen van de wezenlijke betrekkingen tussen de burgers. Het niet optimaliseren van macht betekent bijgevolg het verwaarlozen van datgene waarom gehandeld wordt, de actualisatie van vrijheid. Vrijheid is het raison d'être van politiek. Handelen en vrij zijn vallen samen.

Handelen is ook moreel zelfregulerend. Wanneer de actor de publieke ruimte betreedt, komt hij terecht in een interactief web van menselijke relaties en de opinies, conflicten en intenties die hieraan inherent vastzitten. Als gevolg van deze constellaties zal de handeling bijna nooit het doel bereiken dat de actor 
oorspronkelijk voor ogen had. Zijn invoeging in de publieke wereld brengt een reeks gevolgen met zich mee die onanticipeerbaar en oncontroleerbaar zijn. De intersubjectieve ruimte is in zulke mate sensitief dat "(...) één daad, soms cén woord volstaat om de hele constellatie te wijzigen." (HC, 190). De actor weet bijgevolg niet waaraan hij begint.

Arendt legt uit dat het handelen niet met een traditionele notie van verantwoordelijkheid in overeenstemming kan gebracht worden. Actie is, door het vergeven en beloven dat er inherent aan is, moreel zelfregulerend. Beloven en vergeven beperken de risico's die met het handelen gepaard gaan aangezien ze relatieve stabiliteit en voorspelbaarheid in de publieke sfeer introduceren. Zonder het vergeven zou de polis disintegreren onder het gewicht van onopgeloste vetes, nijd en gramschap. Vergeven en beloven volstaan bij de toewijzing van verantwoordelijkheid. Het belangrijkste criterium bij de beoordeling van een handeling is geen moreel criterium, maar gaat het vermogen tot grootsheid aan : "In tegenstelling tot het gedrag, wat de Grieken volgens 'morele' maatstaven beoordeelden, laat de actie zich uitsluitend beoordelen volgens het criterium van grootsheid omdat het in haar natuur ligt de gemeenplaats te doorbreken en naar het buitengewone te streven. (...) Bij de actie geldt niet wat in de normale leefwereld van toepassing is, omdat al wat verricht wordt uniek en sui generis is." (HC, 246) De toepassing op de actie van een transcendente, niet intersubjectief verkregen, extrapolitieke, verantwoordelijkheidsnotie compromitteert het vermogen tot actie. In plaats daarvan dient ieder handelen op zijn eigen termen, in zijn uniciteit, afgewogen te worden. Het is belangrijk precies te begrijpen wat Hannah Arendt met grootsheid bedoelt. Hoewel publieke interacties intrinsiek competitief zijn richten de actoren zich niet naar het behalen van glorie of succes. Glorie is de paradigmatische motivering van het feodaal-christelijke tijdperk en beantwoordt aan de ondeugden ijdelheid en hooghartigheid. Succes is de onbetwiste standaard van de massasamenlevingen waar de actie nagenoeg is uitgebannen. Succes stemt overeen met de ondeugden nijd en frustratie. Het streven naar excellentie is daarentegen een individuele prestatie in een collectieve onderneming. Wanneer actoren zich onderscheiden versterken zij het machtspotentieel van de gemeenschap in haar geheel. Arendts prototypische politieke actor is Thomas Jefferson of Rosa Luxemburg, niet Benito Mussolini.

Hannah Arendt wil met het verschil tussen werk en actie de assimilatie van politiek met instrumenteel handelen en strategische interacties tegengaan. De scheiding tussen werk en actie betekent niet dat handelen van belangenarticulaties losstaat. Handelen gaat de aardse, alledaagse, belangen aan. Actie onderscheidt zich van werk doordat instrumentele motivaties er nooit alleen staan. De politieke redevoering transcendeert de doelgerichte rationaliteit. Arendts these luidt dat het handelen door doel-middelenrelaties gekoloniseerd is. In de moderne tijd is 
politiek slechts een instrument ten behoeve van maatschappelijke belangenbehartiging. In de welvaartstaten heeft de actie plaatsgemaakt voor een tiranniek administratief beheer. Handelen bestaat uit de combinatie van het nastreven van specifieke belangen en de daaraan gekoppelde articulatie van principes als rechtvaardigheid, deugd, billijkheid. De principes ontsluiten de specifieke betekenis van de daad.

De principes zijn essentieel voor Arendts politieke fenomenologie. Niettemin blijft zij daaromtrent in The Human Condition vaag. Latere besprekingen maken duidelijk waarom. In Between Past and Future (1961) legt zij uit dat de principes bewerkstelligen dat de actiename niet willekeurig is. De principes verzekeren dat de handeling, hoewel zij innovatief is en buiten het gewone valt, met de sensus communis, de intersubjectief verkregen gemeenschapszin van de samenleving, in overeenstemming blijft. In On Revolution (1963) stelt zij dat principes abstracties en generalisaties zijn, produkten van het denken, de (innerlijke) activiteit die zij in haar studie van het (uiterlijke) actieve leven heeft uitgesloten.

\section{De ontmanteling van de filosofie}

Arendts fenomenologie van de vita activa vormt een expliciete kritiek op de antieke en de moderne concepties van politiek en samenleven. De ontmanteling van deze toont aan dat beide, hoe verschillend zij ook zijn, een pervertering van de eigen aard van de politiek vertegenwoordigen. Beide trachten het handelen uit de sfeer van menselijke relaties te verdrijven door er vormen van werk, expertise en hiërarchie, voor in de plaats te stellen. Op deze wijze corrumperen zij de ontologisch correcte hiërarchisering van het handelen in de publieke sfeer, het werk en de arbeid in de private sfeer van de vita activa.

De antieke filosofie situeert het handelen in een contekst van een transcendent gezichtspunt van rechtvaardigheid. Deugden zijn het gevolg van de contemplatie die als een solitair, passief, non-discursief schouwen van waarheid opgevat wordt. Plato's conceptualisatie van de tegenstelling tussen waarheid en opinie en zijn ideeën over het doel van de politiek en het doel van de contemplatie vormen volgens Arendt de basis voor alle verdere traditionele beschouwingen. Hoewel utopieën in de feitelijke geschiedenis geen belangrijke rol gespeeld hebben, inspireren zij een traditie van denken over politiek waarin handelen door maken is vervangen. Plato's idealisme, de tegenstelling tussen Zijn en Verschijning, vormt voor Arendt de meest invloedrijke, meest schadelijke metafysische dwaling van het Westerse vertoog. Dit steeds terugkerende dualisme wettigt het spreken over een traditie : "Sinds Plato (...) wordt de academische filosofie gedomineerd door de nooit ophoudende omkeringen van idealisme en materialis- 
me, van transcendentalisme en immantentisme, van realisme en nominalisme, van hedonisme en ascetisme, enzovoort." (HC, 102) Arendt bekritiseert bijgevolg niet alleen de conceptie van het handelen, maar ook deze van het denken, de activiteit die de filosoof vereert. Plato's theorie leidt niet alleen tot de vertekening van de politiek, maar evenzeer tot een vertekening van de metafysiek. Wanneer de filosoof besluit tot het ontwikkelen van blauwdrukken voor de geordende maatschappij vormt hij het authentieke verslag van de denkervaring als innerlijke dialoog om tot een sprakeloze aanschouwing van essenties, die hij vervolgens in het actieve als standaarden tracht te introduceren. De ervaring leert dat het denken niet uit een sprakeloze contemplatie bestaat. De denkactiviteit beantwoordt aan een hoogst actief gesprek met mijzelf. Wanneer ik denk, streef ik niet naar kennis (het denken is niet het intellect), maar tracht ik de betekenis van mijn ervaringen, in het bijzonder de ervaring van mijn mens-zijn, te begrijpen. Het antieke beschouwen van de contemplatie als een solitair leven, dat met de diversiteit van de vita activa op gespannen voet staat, vormt het verslag van het denken en het handelen tot aan de moderniteit.

De eerste filosofen die met de traditionele conceptie van het handelen en het denken breken zijn historicisten. Hegel en Marx vernietigen de platoonse dualiteit tussen de transcendente waarheid en de wereldse contingentie door de ontvouwing van waarheid als de drijvende kracht van de geschiedenis op te vatten. Daarmee wordt de mens een in de tijd ingeschreven en een tijdconstituerend subject. Theorie wordt dan een reflectie op de menselijke autogenese waarvan de geschiedenis getuigenis aflegt. Arendt wijst het historicisme als een vorm van hubris af. De these dat het denken en het handelen met elkaar door de geschiedenis zijn verbonden, is van het bewijs van het cumulatief-progressieve verloop van de geschiedenis afhankelijk. De vooruitgang is geen entiteit die zich door fenomenologische bewijskracht laat onderbouwen. De teleologische interpretatie van de historicist vernietigt, in de theorie, de vrije daad. In historicistisch perspectief is alle handelen noodzakelijk, niet vrij, geweest. Op deze wijze blijft de actie in het moderne denken in misprijzen gevangen. De consequenties van beide antipodische denkbeelden, de antieke en de moderne, zijn gelijk : Plato en Marx theoretiseren het handelen.

Arendts conceptie van politiek is geschreven met de duidelijke bedoeling, tegen de traditionele theorie, de intrinsieke waarde van de vita activa voorop te stellen. De maatschappijkritiek uit The Human Condition maakt echter duidelijk dat zij ernstige problemen ondervindt de vita activa uit te leggen zonder hier het denken bij te betrekken. De auteur legt uit dat in de door de animal laborans gedomineerde wereld betekenisvolle activiteiten progressief aan maatschappelijke marginalisatie ten prooi vallen. De modemiteit plaatst betekenisvolle daden en werken buiten de leefwereld van het gegevene, met als gevolg dat het gevoel van 
wereldsheid verkleint. In het laatste deel van het werk schrijft Arendt dat betekenisvol handelen in de modemiteit beperkt blijft tot de activiteiten van de kunstenaar en de wetenschapper. Deze opmerking is merkwaardig omdat kunstenaars en wetenschappers niets met actie, zoals het in hetzelfde werk wordt besproken, te maken hebben. Doorheen The Human Condition argumenteert Arendt dat actie het resultaat van een wezenlijk menselijk samenzijn is, dat de actie zijn basis in het common sense begrijpen van de wereld vindt, en dat het belang van de handelingen in het intersubjectief verkrijgen van betekenis ligt. Hoewel het handelen in de theorie door de filosofische traditie en de sociale theorie en in de praktijk door de autonomisatie van de sociale sfeer is aangevallen, is het niet verdwenen. Dat de actie in de (post)moderniteit nog bestaat is niet te wijten aan de common sense en de pluraliteit, maar aan de isolatie die het artistieke scheppen kenmerkt en aan de manipulatie van de moderne wetenschapper die, het experiment transcenderend, substitutief in de natuur is gaan handelen. Hoewel de publieke ruimte nagenoeg geheel vernield is, zodat de mogelijkheid tot actie onmogelijk is, en, anderzijds, werk gradueel bij de metabolische consumptie van de animal laborans wordt betrokken, slagen specifieke geïsoleerde - individuen, er niettemin in zich in betekenisvolle activiteiten te engageren. Dat dit gebeurt schrijft Arendt toe aan het vermogen te denken. Wat in de (post)moderniteit aan werk en actie overblijft is dus niet afhankelijk van de voorwaarden die Arendt in haar boek voor hun bestaan aangeeft.

Zij verdoezelt de inconsistentie niet. The Human Condition eindigt met de overweging dat het denken eveneens een activiteit is. Het werk over het actieve sluit af met de enigmatische uitspraak van de oude Cato "Nooit is hij meer actief dan wanneer hij niets doet; nooit is hij minder alleen dan wanneer hij bij zichzelf is." (HC, 325) Enerzijds sluit Arendt het denken van de ontologie van het actieve uit, anderzijds is een bespreking van deze faculteit vereist voor de verklaring van het problematische behoud van actie in de moderniteit. Ook de uiteenzetting over de principes toont aan dat het handelen niet bevredigend besproken kan worden zonder er het denken bij te betrekken.

\section{Boosaardigheid als gedachteloosheid}

De spanning die in The Human Condition aanwezig is vormt voor de auteur een uitdaging het denken systematisch te onderzoeken. Het project komt in een stroomversnelling wanneer de Israëlis in 1961 Adolf Eichmann naar Jerusalem brengen. Arendt besluit het proces van de oorlogsmisdadiger te verslaan. Eichmanns verschijning overtuigt Arendt ervan dat zijn boosaardigheid niet aan een demonische neiging tot het kwade is toe te schrijven. Daarvoor lijkt de 
misdadiger te vaal, te oppervlakkig. Hoewel het kwaad waarin hij participeert absoluut is, is Eichmann niet zozeer boosaardig dan wel gedachteloos. Zijn kwaad resulteert uit "zijn onvermogen of onwil te denken." Deze meerdere malen gebruikte formule verraadt de oorspronkelijke ambivalentie. Arendt ontvouwt een fundamenteel inzicht over de werking van de geest : de gedachteloosheid volgt uit de autonome beslissing niet langer te willen denken. Eichmann is niet langer in staat goed van kwaad te onderscheiden, omdat de beslissing met denken te stoppen het stillen van het geweten en de uitlevering van het vermogen tot kritisch zelfonderzoek inhoudt : de gedachteloosheid vormt de noodzakelijke voorwaarde voor de boosaardigheid.

De taak van het denken is het behouden of bewerkstelligen van de harmonie tussen de beide partners in de dialoog tussen mij en mijzelf (Plato's eme emauto). De dialoog richt zich op het behoud van consistentie in de gedachten. Wat iemand tot denken aanzet is zijn angst kwaad te doen of zijn vermoeden of realisatie dat kwaad wordt gedaan. De innerlijke bevraging, die inzet met de vraag of ik met mijzelf kan leven, genereert de aporetisch kritisch-dialectische dialoog waarin de denkpartners elkaar voortdurend de (socratische) vraag naar de betekenis van de gebruikte concepten (als billijkheid, rechtvaardigheid) stellen. Deze ondervraging constitueert het bewustzijn. Onnadenkende mensen zijn niet 'vol van spijt', maar leven als slaapwandelaars. Socrates daarentegen, zal $n u$ hij tussen de anderen is, niets onbedachts doen, dat hem, later, wanneer hij bij zichzelf is, tegenover zijn innerlijke partner in moeilijkheden zal brengen. De vrees voor de confrontatie met mijzelf, mijn (subjectieve) geweten vult de mens met obstakels (Shakespeare) en relateert met de onthouding van daden, maar biedt geen inzicht in de positieve relatie tussen de geest en de wereld en beantwoordt hiermee Arendts vraag niet. $\mathrm{Zij}$ wilde niet alleen weten wat het stellen van handelingen in de wereld belemmert of onmogelijk maakt; zij is vooral geïnteresseerd in de processen die in de geest aan het handelen voorafgaan.

In Eichmann in Jerusalem (1963) komt Arendt terug op de analyse uit The Origins of Totalitarianism (1951). Volgens deze analyse is het onmogelijk Eichmann voor zijn daden verantwoordelijk te stellen. In 1951 betoogt Arendt dat de totalitaire terreur en de ideologie niet alleen de publieke ruimte en de private betrekkingen tussen de individuen, maar tevens de innerlijke interacties vernietigen. Eichmann in negatieve, Karl Jaspers in positieve zin overtuigen Arendt ervan dat de geest een bepaalde autonomie tegenover de wereld bezit. Arendt komt terug op de in The Human Condition impliciet aanwezige vordering dat de vita activa op zichzelf, zonder wisselwerking met het leven van de geest, bestaat. Niet alleen is de geest in staat los van de vita activa te functioneren (wat politiek relevant is in historische crisissituaties), mentaal kunnen mensen ook de omstandigheden waarin zij leven overstijgen. Wanneer de intersubjectiviteit 
vernietigd is kunnen mensen met zichzelf blijven spreken en, hierdoor, hun geweten vrijwaren. Het leven in de greep van de terreur pleit Eichmann niet vrij. Eichmann kan beoordeeld worden op grond van 'waarheden' van 'essentiële' rechtvaardigheid die, ongeacht de omstandigheden, door te denken, erkend blijven.

De vraag waarmee Arendt zich na Eichmann in Jerusalem geconfronteerd zag, luidt : hoe kunnen we zeggen dat de hoogste menselijke vermogens zich ontplooien in een actieve en pluralistische contekst van intersubjectiviteit en hoe kunnen we tegelijk van individuen, wanneer zij deze contekst ontberen, eisen dat zij zich op een moreel verantwoorde wijze (blijven) gedragen ? Op welke wijze laat de relatie tussen het leven van de geest en het handelen zich denken? Hieraan koppelf zij tevens de vraag naar het wezen van de moraliteit. Indien een politiek fenomeen, het totalitarisme, er is in geslaagd de moraliteit te vernietigen, wat is de moraliteit dan in wezen?

\section{Het leven van de geest}

The Life of the Mind zet in met een bespreking van het wezen van de moraliteit. Het totalitarisme onthult de moraliteit in haar oorspronkelijke betekenis als een verzameling mores en gewoonten. Het 'morele' probleem van de moderniteit, waarin de traditie, de verbinding tussen religie en authoriteit verloren is gegaan, ligt in het feit dat gewone individuen, zich door een willekeurige verzameling mores 'gedwongen' kunnen voelen. De gewone individuen, die in zich geen neiging tot boosaardigheid 'voelen', reveleren de ware aard van de moraliteit. Het traditionele onbedachte aanleren van regels blijkt inhoudelijk veranderbaar door (een) Hitler en (een) Stalin. Het denken heeft niets met zulk onbedachtzaam aanleren te maken, maar 'conditioneert' ondubbelzinnigheid tegen boosaardigheid. De vraag is hoe deze 'conditionering' zich voltrekt.

Arendt meent dat hoewel het denken in het hart van de tijd werkzaam is, het niet in een factische relatie met de werkelijkheid staat. Het denken manifesteert zich nooit onmiddellijk in de wereld. De denkactiviteit ontvouwt zich metaforisch (metapherein), omdat de afgrond tussen de innerlijke activiteit van het denken en de uiterlijke leefwereld alleen in metaforen kan overbrugd worden : "Metaforen zijn de middelen waarmee de eenheid van de wereld poëtisch uitgedrukt wordt." (Th, 105) De metafoor suggereert gelijkaardige relaties tussen ongelijkaardige objecten of activiteiten en slaat op deze wijze de brug tussen de existentiele staat van het denken en de staat van het handelen. De aanvaardbaarheid van de metafoor is afhankelijk van de poëtische affiniteit die tussen mentale en sensorische data, bijvoorbeeld tussen het gegriefde hart en de zee (Homerus), tussen de wind en het denken (Socrates), kunnen worden onderkend. De 
onomkeerbaarheid van de metaforische relatie duidt niet alleen op de exclusiviteit van de fenomenale wereld. De mogelijkheid niet-zintuiglijke, mentale, beelden te construeren en, hoewel nooit geheel volkomen, over te brengen is afhankelijk van de taal, omdat we ons zonder de taal niet van mentale ervaringen bewust zouden kunnen zijn. De taal zet de abstractie tot een inzichtelijke betekenis om.

Arendt vraagt zich af wat tot denken aanzet. Een antwoord op deze vraag vindt men door bij een 'niet professioneel denker' te rade te gaan - door "een model van een denkend mens te beschouwen." (Th, 167). Socrates is het model van zulk een niet beroepsmatige denker. Hij verenigt in zich de ogenschijnlijk tegenstrijdige passies voor denken en handelen, "(...) niet in de zin dat hij er op uit is theoretische standaarden voor het handelen te ontwikkelen, maar in de veel meer relevante zin dat hij in beide sferen geheel thuis is." (Th, 167) Arendt herhaalt dat wanneer de denkactiviteit aan de gang is de denker alleen maar niet eenzaam is : hij is met zichzelf. Voor de persoon, als fenomenologische eenheid, is het imperatief dat de partners van de denkdialoog tot overeenstemming komen. Uit de conceptie van denken als een twee-in-één dialoog volgt logischerwijs Socrates' uitspraak dat het beter is kwaad te ondergaan dan kwaad te doen. De misdadiger kan er in slagen zijn rechtmatige straf te ontlopen, maar staat machteloos tegen de weerwraak van zijn eigen psyche. Hoewel het denken niet op zich door morele overwegingen wordt gedreven, stelt zij dat iemand die niet naar innerlijke harmonie streeft niet in staat is morele oordelen te vellen.

De analyse van Socrates blijft dicht bij het uitgangspunt van The Life of the Mind, maar wijst op een moeilijkheid waarop Arendt geen antwoord formuleert. Los van de vraag of Socrates met de twee-in-één de denkfaculteit zelf bespreekt, antwoordt zij op de vraag wat mij aan mijzelf vragen doet stellen, dat denken aan een natuurlijke behoefte beantwoordt : eenmaal ik ontdekt heb dat dit mogelijk is, is het normaal dat ik met mijzelf praat. Indien dit zo is, maar in omstandigheden waar het denken, hoewel moeilijk, mogelijk blijft, sommigen hun denken verzaken en anderen onbewogen hun denken blijven actualiseren, dienen in de analyse bijkomende factoren betrokken te worden. De uiteenzetting over Socrates maakt duidelijk dat Arendt de - pregnante - vraag wat niet doet denken niet bevredigend beantwoordt. Arendt schreef dat de oneindige bevraging naar de betekenis van de dingen zich op ieder moment tegen zichzelf kan keren. Maar zij verduidelijkt niet waarom dit zich bij de ene wel, bij de andere niet voordoet.

Arendt bespreekt in het Postscriptum van Thinking de structuur van The Life of the Mind. Het tweede deel zou de bespreking over het willen en het oordelen bevatten. De reden achter deze indeling is duidelijk : het willen en het oordelen hebben, ondanks hun tegengestelde temporele oriëntatie, met elkaar gemeen dat zij over bijzonderheden handelen. Filosofen hebben onderzoek naar het oordelen lang veronachtzaamd. Pas met Kants derde kritiek wordt het oordelen een 
belangrijk onderwerp van een eminent denker. Arendt postuleert in Thinking ook de autonomie van de oordeelsfaculteit : het oordelen is geen vorm van redeneren maar heeft, strikt gesproken, niets met logische operaties te maken. De autonomie van het oordelen :

\begin{abstract}
is relevant voor een hele serie problemen die het moderne denken achtervolgt, in het bijzonder voor het probleem over de relatie tussen de theorie en de praxis en voor alle pogingen een halvelings plausibele ethiek te ontwikkelen. (...) Sinds Hegel en Marx zijn deze vragen gesteld vanuit het perspectief van de Geschiedenis en onder de assumptie van de Vooruitgang. Wij kunnen het ultieme oordeel overlaten aan het Succes of we kunnen, met Kant, de autonomie van de menselijke geest weerhouden. Indien dit juist zou zijn kunnen we onze menselijke waardigheid opeisen, haar terugwinnen van de pseudo-godheid van de Geschiedenis die we het recht ontzeggen de ultieme rechter te zijn. (Th, 272)
\end{abstract}

Willing zet in met een waarschuwing. Over de wil bestaan nog minder onbevooroordeelde bronnen dan over het denken. Filosofen vereren het denken en misprijzen het willen. Het filosofische onbehagen tegenover de wil vindt zijn neerslag in een "(...) buitengewone hoeveelheid ingenieuze theorieën en doctrines die losstaan van de ervaring van het willende ego en niet gericht zijn op 'het redden van de fenomenen'." (W, 3) Filosofen willen de wereld interpreteren, niet veranderen. De wil is daarentegen "de springplank van het handelen." (W, 11) Willen gaat niet de deliberatie over algemeenheden, maar het vormen van projecten aan. Willen kenmerkt zich, door zijn oriëntatie naar de toekomst, door onzekerheid. De auteur vergelijkt het denken en het willen met verschillende tonaliteiten. De tonaliteit van het denken is sereniteit en melancholie (Hegels Ruhe der Vergangenheit). De tonaliteit van het willen bestaat uit gespannenheid, een mengsel van hoop en vrees, die de overweging onmogelijk maakt. De wil vindt geen voldoening in zichzelf, maar staakt het uitvaardigen van bevelen slechts wanneer van een project een begin van uitvoering gemaakt wordt. Ook dan verdwijnt zijn onrust niet, omdat niets het welslagen van de onderneming verzekert. De wil wil steeds initiëren en staat daardoor met impliciet misprijzen tegenover het denken. Het denken, op zijn beurt, doet het bestaan van een autonome, vrije wil af als een hersenspinsel.

De wil is niet de faculteit die kiest tussen gegeven mogelijkheden. Om het liberum arbitrium van de wil te onderscheiden bespreekt Arendt de evolutie van de homo temporalis. In het kader van een cyclisch (Grieks) tijdsconcept blijft een 'orgaan voor de toekomst' buiten beschouwing. In de contekst van een lineaire tijdsopvatting, waarin unieke gebeurtenissen mogelijk zijn, wordt de wil als autonome faculteit onmisbaar. Arendt vindt het bewijs van de autonomie bij 
Augustinus die het fenomeen onderzoekt dat het mogelijk is te willen en, zonder externe hindernis, niettemin onmogelijk is te handelen. Elk willen genereert een tegen-willen, geen ik-wil-niet, maar een actief nillen. Het gelijktijdige optreden van wil en tegenwil kenmerkt de faculteit van de wil. De opvatting wordt onderbouwd door de vaststelling dat de wil ook op dwingende wijze tot zichzelf spreekt. Arendt aanvaardt Scotus' theorie dat de wil vrij en autonoom maar niet omnipotent is. Het verleden en de factualiteit vormen de limieten van de wil. $\mathrm{Zij}$ kant zich tegen Augustinus' en Scotus' conceptie van de heling van de wil met de tegenwil. Alleen het concretiseren van een project van de wil vernietigt de wil als te realiseren mogelijkheid.

Augustinus en Scotus leveren de meest onbevangen inzichten in de werking van de wil. In het Duitse idealisme wordt de wil een gepersonifieerde metafysische entiteit of ontologische categorie, een benadering die ons niets kan leren over de wil als geestelijke faculteit. Ook de gedachten van Nietzsche en Heidegger, de laatste twee belangrijke denkers die dicht genoeg tot het Westerse vertoog staan om in de wil een belangrijke faculteit te erkennen, dragen weinig tot het begrijpen ervan bij. Nietzsche worstelt met het probleem dat, indien het leven tot hoogste waarde verheven wordt, dit de wil met zijn temporele begrenzing confronteert. Omdat het onmogelijk is het gedane te veranderen dringt de wil het intellect de idee van een cyclisch tijdsconcept op. Van het onvermogen dit idee te aanvaarden leidt Nietzsche het ressentiment, de naijver, de wil tot wraak, de genealogie van de moraal, kortom al het kwade af. Tegen Nietzsches inspanning de wil als een destructieve, mentaal almachtige grootheid te beschouwen, stelt Heidegger 'een denken dat geen willen is.' Deze gelatenheid valt buiten het domein van de wil. $\mathrm{Zij}$ is een denken dat het $\mathrm{Zijn}$ als de beslisser erkent. Op deze wijze verkrijgt het denken bij Heidegger de betekenis een handelen te zijn: het bieden van weerstand tegen de wil.

Arendt slaat een andere weg in. $\mathrm{Zij}$ keert zich naar de politieke actoren in de hoop bij hen een filosofisch onbevooroordeelde conceptie van vrijheid aan te treffen. De politieke vrijheid, het samen handelen, is, in tegenstelling tot de filosofische vrijheid, het dwingend-solitaire ik-wil, afhankelijk van het ontstaan en bestaan van gemeenschappen. Politieke vrijheid hangt af van het moment waarin groepen zich omzetten tot een distinctief 'wij'. Dit moment blijft steeds mysterieus : de gedachte van een absoluut begin refereert naar een niets dat voorafgaat aan een daad die zich niet causaal laat uitleggen en is daardoor ondenkbaar. Arendts actoren blijken, zoals de representatieve denker, Socrates, niet geheel adequaat. Zoals het socratische denken zich niet met het kwade confronteert, ontlopen de actienemers een onderkenning van dat wat zonder precedent is. Ook hun inzichten zijn niet werkelijk onbevangen. De vorming van gemeenschappen draagt een element van louter toeval en willekeur in zich 
waarvoor ook de meest onverschrokken actoren achteruit deinzen. Arendt spreekt over de afgrond van de zuivere spontaniteit. De afgrond beantwoordt aan het besef dat wat werd gedaan ongedaan had kunnen blijven, maar niet meer ongedaan kan gemaakt worden. De afgrond is in het westerse vertoog door denigratie tegenover vernieuwing opgevuld. Politieke vrijheid overleefde in de politieke theorie nagenoeg uitsluitend in utopische, ongefundeerde, profetieěn over een finale sfeer van de vrijheid 'op het einde van de geschiedenis.'

Tegen zulke postuleringen kent Arendt uiteindelijk slechts één filosoof, Augustinus, die het innoveren in de nataliteit (Augustinus' mirakel van de geboorte), niet in vooruitgang plaatst. Dit resultaat frustreert omdat "(...) zelfs de augustinische versie niet meer schijnt te zeggen dan dat we gedoemd zijn vrij te zijn, ongeacht of we vrijheid koesteren of de willekeur ervan ontvluchten door een vorm van fatalisme aan te hangen (...). Deze impasse kan slechts opgelost worden door een beroep te doen op de oordeelsfaculteit." (W, 217) Ook wanneer de wil niet getheoretiseerd wordt en het meest uit de ervaring gesproken wordt, draagt hij een element van dwang in zich. Op de vraag hoe, gezien deze dwang, de menselijke waardigheid gevrijwaard wordt, blijft ook Augustinus het antwoord schuldig. Judging droeg de belofte de oplossing uit deze impasse te bieden.

Hannah Arendt heeft het laatste deel van The Life of the Mind niet kunnen schrijven. Zij overlijdt na het beëindigen van Willing. Van Judging bestaat slechts de titelpagina, voorzien van twee epigrafen. De gedachten over het oordelen laten zich reconstrueren aan de hand van de lezingen over Kants politieke filosofie waarover zij vanaf 1964 doceert. Ook in The Life of the Mind weidt zij over het oordeel uit. Het oordeel is geen phronesis, een praktische rede en wijsheid die verbonden is met de keuze tussen gegeven mogelijkheden. De phronesis is een voorloper van het oordelen, niet het werkelijke oordelen zelf. Het oordeel is ook niet de smaak die tijdens de achttiende eeuw los van de praktische wijsheid komt, maar dan ook zijn idiosyncratische betekenis verkrijgt : over smaak valt niet te twisten. Tegen de vermeende idiosyncrasie van de smaak en het oordeel keert Kant zich in de Kritik der Urteilskraft. Smaken sorteert een onmiddellijk effect van goed- of afkeuring. Oordelen kenmerkt zich door reflectie. De smaak is valide indien hij geschikt is om meegedeeld te worden. Deze communicatie is van de sensus communis van de gemeenschap afhankelijk. In de Lectures gaat het niet zozeer om de common sense in Arendts gebruikelijke betekenis van een zesde, overkoepelend en coördinerend zintuig (Kants gemeiner und gesunder Verstand), maar om de sensus communis, een extra-zintuigelijk, gemeenschapszinregulerend, vermogen (Menschenverstanden). Het onderscheid beklemtoont de interactieve dimensie van de gemeenschapszin.

$\mathrm{Bij}$ het oordelen verbeelden we het aan de zintuigen afwezige fenomeen en beoordelen we de smaak. De verbeelding zet een object om tot de representatie 
ervan. Deze terioriseert zich zodat ik niet langer van het feitelijke object afhankelijk ben. Ik ben niet langer betrokken. De onbetrokkenheid waarborgt de relatieve onpartijdigheid van het oordeel maar niet de bekwaamheid ervan. Hiertoe keert Kant zich tot de sensus communis : het oordeel is valide indien de validering intersubjectief gebeurt. Oordelen houdt dan 1) een zintuigelijke waarneming die tot de smaak aanleiding geeft in; 2) een representatie van de waarneming door de verbeelding; 3 ) een evaluatie van de smaak die in de goed- of afkeuring ervan resulteert; 4) een anticiperend afwegen van de mogelijke oordelen van anderen over het oordeel; 5) het intersubjectief zoeken naar validiteit over het oordeel. Oordelen is inherent sociaal omdat esthetische en politieke oordelen tot een gemeenschappelijke wereld appeleren waarin zij validiteit kunnen verwerven. De wil tot communicatie is bij het oordelen niet extern of bijkomstig, maar geheel wezenlijk. Zoals het denken bestaat tussen mij en mijzelf en de wil in een wil en een niet-wil uiteenvalt, splitst het oordeel zich in een mij en een (verbeeld) wij. De schoonheid van een object of de grootsheid van een gebeurtenis bevredigt het oordeel alleen indien er bij anderen overeenstemming over aangetroffen wordt. Oordeel vereist 'consideratie' omdat de mens een politiek wezen is : "(...) we zijn 'geconsidereerd' [we are 'considerate'] in de oorspronkelijke betekenis van het woord. We overwinnen onze specifiek subjectieve verlangens terwille van de anderen. (...) Het niet-subjectieve element in de niet-objectieve zintuigen is de intersubjectiviteit." (LKPP, 64-65)

De moeilijkheid die zich voordoet is dat niet de actoren in de publieke ruimte maar de toeschouwers oordelen. De actor is betrokken en beschikt over geen globaal overzicht over hetgeen gebeurt. Handelen en onpartijdig oordelen sluiten elkaar uit. De vraag is dan hoe de actor zich concreet tot de toeschouwer, Kants wereldburger, verhoudt. Wie is de toeschouwer eigenlijk ? Bij gebrek aan een uitgeschreven politieke theorie bij Kant beantwoordt Arendt de vraag door na te gaan hoe de kunstenaar zich bij Kant tot de kritiek verhoudt.

Kant stelt de vraag naar de verhouding tussen kunst en smaak. Het genie, de kunstenaar, onderscheidt zich door zijn productieve verbeelding en originaliteit. Zonder het genie kan kunst niet worden gemaakt, maar zonder de smaak kan kunst niet worden beoordeeld. Kant legt uit dat louter genialiteit niet volstaat : zonder de binding met de sensus communis creěert de kunstenaar in zijn ongebonden rijkdom slechts onzin. De objecten die de kunstenaar maakt appeleren aan een gemeenschappelijk gevoelen (allgemeine Gemütszustand) dat het genie exemplarisch veropenlijkt. In de conceptie van kunst als uiting van een gemeenschappelijk gevoelen vormt de communicativiteit, het vermogen zichzelf begrijpelijk te maken bij hen die geen kunstenaars zijn, het criterium voor het esthetische oordeel. 
Het laatste deel van de Lectures behandelt de voor het oordelen noodzakelijke tertium comparationis. Indien het oordelen autonoom werkzaam is, wordt het bijzondere vergeleken met iets dat ook een bijzonderheid is. De bijzonderheid waarmee vergeleken wordt, draagt echter een algemeenheid in zich. Anders is het oordelen niet mogelijk. De bijzonderheid die een algemeenheid in zich draagt, vindt Arendt in het exemplarische voorbeeld van de representatieve figuren : "Hoe kun je een daad als moedig beoordelen ? Wanneer je oordeelt zeg je spontaan, zonder afleiding van algemene regels : deze persoon heeft moed. Indien je een Griek zou zijn, zou in je geest het voorbeeld van Achilles leven. Het oordeel bezit exemplarische validiteit naarmate het voorbeeld juist gekozen is." (LKPP, 82) Dit spontane kiezen is echter van een voorafgaand denkproces afhankelijk. De figuur die als exemplarisch voorbeeld van moed aangehaald wordt, moet werkelijk moedig zijn. Zo wordt duidelijk waarom Arendt oordelen een zij-effect van denken noemt. Het is slechts mogelijk spontaan over bijzonderheden te oordelen, indien over het wezen ervan vooraf nagedacht is. De Lectures on Kant's Political Philosophy sluiten af met een passus die aan de slotpassages van Thinking en Willing herinnert : "De waardigheid van de mens vereist dat daden op zich, los van alle procesdenken, beoordeeld worden. (...) De idee van de vooruitgang is strijdig met Kants notie van de waardigheid van het individu." (LKPP, 85).

De passage leent zich tot een interpretatie van de epigrafen waarmee Judging was ingezet. Deze zijn : "Vitrix causa deis placuit, sed victa Catoni" en "Könnt' ich Magie von meinem Pfad entfernen, / Die Zaubersprüche ganz und gar verlemen, / Stünd' ich Natur vor Dir, ein Mann allein, / Da wär's der Mühe wert, ein Mensch zu sein." (Goethe) Het oordelen stelt niet alleen in staat te onderscheiden tussen goed en kwaad, mooi en lelijk, maar vervult ook met melancholie. Deze kan worden ontvlucht door een historicistisch-teleologische interpretatie van de geschiedenis aan te hangen. Precies dit escapisme tast de waardigheid van de mens aan. Deze waardigheid wordt alleen gevrijwaard wanneer daden niet aan één van de grote narratieven ondergeschikt wordt gemaakt. Niet de geschiedenis en het succes maar de over betekenis reflecterende toeschouwer die zich van deterministische illusies heeft bevrijd, is de geijkte rechter van de menselijke handelingen. Op deze wijze wordt de uitspraak begrijpelijk dat het ultieme alternatief voor een theorie over het oordelen tussen Kant en Hegel ligt.

De vraag naar de verhouding tussen de actor en de toeschouwer heeft Ronald Beiner, die The Lectures heeft uitgegeven en van een interpretatief essay heeft voorzien, op een verkeerd been gezet. Beiner vindt in de bespreking van Kants visie op het genie en de kritiek het bewijs van de absolute scheiding tussen de toeschouwer en de actor bij Arendt. ${ }^{4}$ De kritiek beoordeelt wat het genie vervaardigt. Bijgevolg vindt volgens Beiner het oordelen uitsluitend op 
retrospectieve wijze plaats bij de toeschouwers, niet bij de makers of de actoren zelf. Deze lectuur is gewoonweg niet realistisch. Het genie is geen wezen dat in volstrekte afzondering ex nihilo creëert en vervolgens schuchter naar de beoordeling van zijn werk uitziet. Het genie staat in een reflectieve en synthetiserende relatie met de tijd waarin hij leeft. Zijn scheppingsproces wordt door zijn eigen kritiek en door de kritiek van anderen gestuurd. De toeschouwer deelt met het genie niet de originaliteit en de creativiteit, maar de faculteit die beiden gemeen hebben is het vermogen te oordelen.

Dit geldt ook voor het handelen. Het oordelen vereist een terugtrekking uit de interactieve wereld. De reflectie en de sereniteit die de langzame overweging kenmerkt zet de initiële smaak om tot een volwaardig oordeel. De oorspronkelijke reactie van de smaak vormt de eerste, noodzakelijke, voorwaarde om te kunnen oordelen. De actor vormt zich een oordeel over wat hij doet wanneer hij de publieke ruimte (tijdelijk) verlaat voor de beslotenheid van het private. Ondanks Plato is er geen fysieke segregatie tussen wie handelt en wie denkt en oordeelt. Arendt schrijft polemiserend dat indien de beoordeelaar niet in iedere maker en in iedere actor aanwezig zou zijn, de maker van dingen en de steller van daden zo ver van de toeschouwer verwijderd zouden blijven dat hun bestaan niet eens zou opgemerkt worden.

\section{Geest en wereld}

De inzichten in de principes, in de metafoor, in de communicatief verkregen gemeenschapszin en in de intersubjectieve validering stellen ons in staat de relatie tussen het leven van de geest en het handelen in de wereld positief te omschrijven. Het handelen is vernieuwend en gaat buiten de orde maar is, door de binding aan een principe, niet willekeurig. Arendt legt uit dat de bron van een principe niet het intellect is. Principes opereren, in tegenstelling tot motieven, niet vanuit het zelf, maar inspireren als het ware van buitenuit en zijn, hoewel elk specifiek doel zich laat beoordelen in het licht van het principe dat zich in de actiename manifesteert, veel te algemeen om welomschreven doelen voor te kunnen schrijven. Een principe valt evenmin samen met het doel van een actie. Principes kunnen, in tegenstelling tot eenmalige doelen, oneindig worden herhaald. Wat bij de bespreking van de principes uit The Human Condition, Between Past and Future en On Revolution achterwege blijft is hun onuitspreekbaarheid. Principes zijn onuitspreekbaar omdat zij denkproducten zijn. De vraag is dan op welke wijze de principes in de wereld een neerslag kunnen vinden.

Het denken levert metaforen, de vorm waarin het onuitspreekbare, het product van de bewonderende verwondering, in het gegevene een plaats verwerft. 
Omdat het denken niet in een factische relatie tot de concrete werkelijkheid staat kan deze omzetting zich niet voltrekken zonder de oordeelsfaculteit. Het denken en het oordelen vinden elkaar in de deliberatie over het exemplarische voorbeeld dat in de vertooggemeenschap vervolgens als tertium comparationis dienst doet. Het denken bereidt de geest door het leveren van abstracte beelden voor op het maken van specifieke, contekstgebonden, oordelen terwijl het oordelen een wereldse gedaante schenkt aan het universalisme, het 'nergens' van het denken : "(...) het oordelen is de faculteit die het bijzondere denkt, maar denken betekent steeds generaliseren; het oordeel is bijgevolg de faculteit die op mysterieuze wijze het bijzondere en het algemene met elkaar combineert." (LKPP, 76) Denken en oordelen verhouden zich tot elkaar zoals het bewustzijn en het geweten : "Indien het denken de twee-in-één actualiseert zoals het in het bewustzijn gegeven is en, daardoor, als zij-effect, het geweten genereert, dan realiseert het oordelen, het bijproduct van de denkactiviteit zelf, het denken in de wereld van verschijningen. (...) De verschijning van de innerlijke dialoog manifesteert zich niet in kennis, maar in het vermogen goed van kwaad te onderscheiden." (Th, 193)

Het oordelen gaat over bijzonderheden die in deze hoedanigheid in een contingente relatie tot het universele staan. Het beroep op het exemplarische voorbeeld verzekert dat het oordeel, en de actiename die er eventueel uit resulteert, met de sensus communis van de gemeenschap in overeenstemming is. Het oordelen voorziet de metaforen van een wereldse gedaante maar stelt er geen definitie over samen. Een definitie is terug een abstractie die als zodanig niet in de wereld terug te vinden is. Het oordelen zoekt in de verschijnende wereld naar een exemplarisch voorbeeld waar de metafoor aan beantwoordt. Op deze wijze voorziet de intersubjektieve praktijk de abstracte beelden over rechtvaardigheid, deugd, billijkheid, van een contekstuele betekenis. De interactie tussen het denken en het oordelen, de combinatie van een universele, geestelijke, met een specifieke, wereldse, grootheid, levert de enige wijze waarop een 'filosofische waarheid' (aanhalingstekens van Arendt), een ethisch principe in de gemeenschappelijke wereld kan geïntroduceerd worden zonder hiermee de vrijheid om te handelen te corrumperen. Het principe dat in de gemeenschap als exemplarisch voorbeeld een 'standaard' constitueert is niet van een aangenomen of opgedrongen 'hogere bron' afgeleid en gaat niet gepaard met een vorm van extrapolitieke sanctionering :

(D)it leren door middel van voorbeeld is de enige vorm van 'overtuiging' waartoe de filosofische waarheid in staat is zonder corrumpering of distortie (...). (D)e filosofische waarheid kan 'praktisch' worden en actie inspireren zonder de regels van de publieke sfeer te schenden op voorwaarde dat zij zich manifesteert in de vermomming van een voorbeeld (...). (D)it is de enige kans voor een ethisch principe om zowel geverifieerd als gevalideerd te worden. (BPF, 246-248) 
Deze eis vertegenwoordigt de kern van Arendts politieke theorie. Alle filosofische constructies waarin over 'hogere bronnen' en het schouwen of kennen ervan gesproken wordt gaan samen met het formuleren van exclusiviteitspostulaten, met het onderscheiden in de gemeenschap tussen wie bepaalde standaarden kent en wie ze niet kent. Op deze wijze hebben politieke filosofen getracht hiërarchie aan de menselijke betrekkingen inherent te maken. Op deze wijze heeft het denken in termen van hiërarchie bij het denken over politiek axiomatische waarde verkregen. Arendt schreef dat zolang de politieke theorie niet het gezonde verstand van de leden van de vertoogsgemeenschap tot het onderwerp van de verwondering maakt zij niet tot de studie van de menselijke betrekkingen bijdraagt. Tot dan zal politieke filosofie niet meer zijn dan politieke doctrine. Hiermee is de uitspraak begrijpelijk gemaakt dat "de principes volgens dewelke we handelen en de criteria volgens dewelke we oordelen en onze levens leiden uiteindelijk van het leven van de geest afhankelijk zijn" (Th, 72).

\section{Noten}

'Citaten worden door letters aangeduid : HC verwijst naar The Human Condition, A Study of the Central Dilemmas Facing Modern Man, (University of Chicago, Chicago, 1958), BPF staat voor Between Past and Future, Eight Exercises in Political Thought, (Harcourt, Brace, New York, 1961), EJ staat voor Eichmann in Jerusalem, A Report on the Banality of Evil, (Penguin, New York, 1963), OR staat voor On Revolution (Penguin, New York, 1963). Th verwijst naar Thinking, het eerste volume van The Life of the Mind, W staat voor Willing (Ed. Mary McCarthy, Harcourt Brace, New York, 1978). LKPP staat voor Lectures on Kant's Political Philosophy (Ed. Ronald Beiner, Chicago University Press, Chicago, 1982).

${ }^{2}$ Voor biografische gegevens raadplege men Elizabeth Young-Bruehl : Hannah Arendt : for Love of the World, Yale University Press, New Haven/Londen, 1982.

${ }^{3}$ Zie Ronald Beiner (ed.) Lectures on Kant's Political Philosophy, (Chicago University Press, Chicago, 1982) Interpretatief Essay, 103 e.v.; Elizabeth Young-Bruehl : "Reflections on Hannah Arendt's The Life of the Mind," Political Theory, Vol. $10 \mathrm{nr}$. 2, blz. 277-305; George Kateb : Hannah Arendt, Politics, Conscience, Evil, Oxford University Press, Oxford, 1983; Bart Prins : Op de Bres voor Vrijheid en Pluraliteit, Politiek in de pastmetafysische revisie van Hannah Arendt, VU Amsterdam, 1990. Zie echter Jerome Kohn : "Acting/Thinking," Social Research, Vol. 54, nr. 1, 1990, blz. 105-34.

'Zie Ronald Beiner (ed.) : Lectures on Kant's Political Philosophy, Interpretative Essay, 1982, 103 e.v.; Zie over procesdenken tegenover een Benjamins geïnspireerd verhalen William Denayer : "Theorie versus illuminatie, Hannah Arendt over de oorsprong van het totalitarisme," Tijdschrift voor Sociale Wetenschappen, Vol. 38, 1993, nr. 2, blz. 141-70, blz. 130 e.v. 